Article

\title{
Reinterpreting the Connotation of "Sustainability" and the Expansion of Social Policy in China
}

\author{
Tao Liu ${ }^{1,2, *}$, Yuxin $\mathrm{Li}^{2}$ and Tong Tian ${ }^{2, *}$ \\ 1 School of International and Public Affairs, Shanghai Jiao Tong University, Shanghai 200030, China \\ 2 Faculty of Social Sciences, the Institute of East Asian Studies, Forsthausweg 2, 47057 Duisburg, Germany; \\ yuxin.li@uni-due.de \\ * Correspondence: tao.liu@uni-due.de (T.L.); tong.tian@uni-due.de (T.T.)
}

Received: 15 February 2019; Accepted: 22 March 2019; Published: 26 March 2019

check for updates

\begin{abstract}
This article examines the interplay between welfare ideas and institutional development and then seeks to explore the ideational background for social policy expansion in China. It focuses on the welfare semantics and narratives that underpin the grand social policy transformation since the millennium. The primary research question concerns whether the approach of "sustainability" is related to social policy in China, and, if yes, how and to what extent. Through the analysis of academic literatures and government documents on social policy in China, we explore the new "sustainability approach" to Chinese social policy that is constructed by social experts and international agencies. While the old sustainability approach overwhelmingly links the "sustainable development" of social policy to the issue of financial affordability and the adequacy of benefit levels, the newly interpreted approach highlights the significant meaning of social policy for long-term and inclusive development over the upcoming decades. Against this backdrop, a holistic national plan for socio-economic modernization has incorporated social policy. Beyond economic and ecological objectives, social development with a focus on social policy has become a key pillar of sustainable development in China.
\end{abstract}

Keywords: social policy; expansion; sustainability; inclusive; development

\section{Introduction}

Over the previous two decades, Chinese social policy has undergone historically unprecedented development. In fact, a social protection net—-the largest and densest worldwide—has been established, which incorporates the majority of Chinese residents into a comprehensive social safety net at lightning speed. In 2016, the International Social Security Association (ISSA) awarded the Chinese government for its extraordinary achievements in extending social protection programs to most Chinese people, particularly in the field of old age insurance and health insurance [1]. While taking into account this remarkable social policy expansion-especially in the area of social insurance and basic income security, the primary focus of this research concerns welfare semantics, including ideas, discourses, scripts, and interpretations of sustainability and social policy in China that are made by relevant actors, including scholars, experts, and officials from Chinese think tanks, research institutes, and government departments. The primary research question concerns whether the approach of "sustainability" is related to social policy development in China and, if yes, which interpretative patterns of this approach have emerged in the Chinese context. The term "sustainability" is polysemous, heterogeneously understood in different socio-linguistic contexts. Scholars, like Bolognesi, have linked the concept of "sustainability" to urban water governance and constructed different models of "sustainability", differentiating the economic, social, and environmental pillars of sustainability. Further, Bolognesi has elaborated on the tensions and the antagonistic relationships between the economic pillar and other 
pillars of sustainability, as derived from the incompatibilities between the principles of the governance of modernization and its objectives [2,3]. The polysemy and multiple connotations of "sustainability" contribute to the complex relationship between "sustainability" and actual policy developments, since different meanings of "sustainability" can be linked to different norms, values, and conceptual models, which could result in opposite directions in public policy development. How social policy in China is related to the different pillars and interpretative patterns of sustainability remains a gap in research in both Chinese and international academia.

Through the analysis of the ideational level of social policy development and the interplay between ideas and practical developments in the legal and institutional context, this article proposes the approach of "reinterpreting the connotation of 'sustainability'" in the Chinese context. It argues that the popular "sustainability approach" - which emphasizes financial affordability and the adequacy of benefit levels-has seen competition from a new approach in the post-millennial age, which regards social policy as a prerequisite for China's sustainable and enduring development, which is no longer solely related to fiscal sustainability, but rather to the sustainability of holistic social development. Moreover, this ideational and semantic transition has attenuated the diffusive skepticism and critical attitudes in Chinese society towards social policy that is based on an economic and monetary lens, while strengthening a new discourse of social sustainability that highlights the prominent role of social policy for China's grand social transformation. New semantics on social sustainability provide a legitimate foundation for social policy expansion in China. The reinterpreted meaning and the new vision of sustainability are key in understanding social policy expansion in China, providing an alternative explanatory approach to the functionalist model, which primarily attributes social policy developments to industrialization, urbanization, and the transformation from a planned economy to a market economy $[4,5]$.

Further, this article connects to the study of global social policy and the theory of "international socialization", which posits an independent global arena of normative and cognitive structures [6,7], highlighting the fact that the national knowledge market in the field of social policy is no longer a closed and isolated market, and that national epistemic communities increasingly interact with the international scientific world. Chinese scholars have extensively borrowed ideas and concepts from Western countries and international agencies to make their national discourses credible in the national science market. The international knowledge market provides sources of legitimation for national ways of narrating and interpreting social policy ideas. Increased integration into the international community has influenced state behavior, resulting in "semantic isomorphism", in which Chinese narratives have begun to resemble international narratives, even in the face of China's unique culture and local social traditions. The national knowledge market has reflected the differentiated and competitive discourses at the international level.

\section{Theoretical Framework}

\subsection{Institutional Interplay between Welfare Ideas and Institutions}

Ideas regarding welfare-including values, norms, semantics, discourses, and cognitive concepts-play a significant role in promoting social policy development and shaping its direction in different social-cultural contexts. Ideas assume the function of constituting a normative and conceptual framework for the general interactional and behavioral patterns of actors in a given social context, additionally contributing to the legitimation of institutional reform choices and paths that are chosen by actors and agencies [8,9]. Institutional developments can also generate new ideas from social practices, in this case, ideas and institutions are located in circular interaction and entanglement. Lessenich and Kaufmann have grappled with studies on welfare semantics, arguing that some basic ideas, such as "security", "equality", "liberty", and "solidarity", have constituted the normative and cultural background of various welfare states $[10,11]$. Against this backdrop, values and norms have framed the institutional settings and organizational patterns of welfare states at the ideational level. 
Encountering a highly complex societal environment, actors and agencies are regularly required to selectively absorb ideas and thoughts from their environment and then develop an ideational and cognitive framework to underpin their concrete institutional actions and common behavioral patterns [12]. Creating personal and institutional preferences for certain ideas from the societal environment contributes to the reduction of complexity and the control of contingency in the social world. In other words, individuals, agencies, and institutions-as well as social groups, such as epistemic communities [13] and advocacy coalitions [14-16] — regularly select their preferred concepts from a repertoire of ideas, scripts, and narratives to constitute their core beliefs [17]. Being endorsed by socially internalized ideas and beliefs, actors and agencies can achieve an extensive and broad consensus, promoting social changes and innovative reforms in an efficient and collective way. Institutional reforms are usually facilitated by the effectively propagated ideas of a well-organized and powerful scientific and political community.

For the above-mentioned reasons, research regarding the perception and interpretation of ideas by actors and agencies is conducive in uncovering the ideational communication field that underlies social institutions. The reconstruction of discourses and narratives that were proposed by actors will deepen our cognitive understanding of why social transformation has occurred, including its ideational and normative foundation. Tracing influential personalities, powerful epistemic communities, and think tanks-along with their normative and cognitive discourses-will contribute to "unlocking" the social "secrets" of institutional change and transition in a period of critical junctures and turning points in a transforming society. For instance, the primary institutional transition in Chinese social policy includes the adoption of new statutory programs, such as the non-contributory social pension for urban and rural residents. This article will show that a newly interpreted "sustainability-approach" has legitimated new social policy institutions and programs that have been adopted since the millennium.

\subsection{Global Social Policy and the International Socialization Approach}

In an increasingly interconnected and cosmopolitan world, researchers studying various areas-such as the economy, financial transactions, climate protection, and social movements, among others have extensively investigated the communication field that extends beyond the national territory. The overarching narrative of globalization is not only confined to the economic, financial, ecological, and environmental fields. Since the late 1990s, scholars have revealed that social policy has also been incrementally "globalized" [18]. Academic interest in global social policy has been mostly directed at how supranational entities and agencies have influenced social reforms and changes in transformation societies, including post-communist states and emerging economies [6]. The significant role of international governmental and non-governmental organizations, like the World Bank and the International Labour Organization (ILO)—as well as world regional actors, like the European Union-in shaping social policy in the national context has been elaborated $[6,19]$. Scholars from the research field of global social policy have shown that some globally constructed "principles" - such as the multi-pillar insurance model in old age pension reform —have been disseminated worldwide [20], and this standardized script has been modified and adapted to national social, political, and cultural configurations [21]. While in some areas—like the global old age pension-competitive discourses and narratives constitute a "war of positions" [22], semantic and verbal communications in other areas-like global health policy and global social protection against accidents-are characterized by globally proposed and condensed prescripts [23] and consensus [19,24]. Different global social policy fields have demonstrated uneven and heterogenous development trajectories and conflict dynamics [25].

With the emergence of a global communications field of social policy, the national path is no longer exclusively "national". The idea of a "national container"—even in the field of social policy-has been largely discredited. In many cases, the national expression of ideas closely dovetails with a communication arena of global social policy that has steadily generated norms, values, and cognitive rationalized social models that are based on experiences from "early bird" welfare states (e.g., the 
Bismarckian social insurance model), and also sporadically from the Global South-such as the capital-funded pension from Chile [26] and the model of conditional cash transfer from the Latin American continent [27].

The rise of international governmental organizations and supranational entities as relevant bodies influencing nation states and subnational actors has been extensively traced while using the theoretical approach of "international socialization" [28]. Nation states have increasingly abided by international beliefs and values, not because they are exposed to international coercion [29]. Many international regulations and conventions-particularly in the arena of social and environmental issues-only contain "soft power" and declaratory and symbolic meaning, without being linked to an effective coercive mechanism, such as the core labor standards that were proposed by the ILO. Instead, nation states have internalized beliefs and values that were forged by international entities and agencies and socialized their behaviors in the international interaction and communication arena $[28,29]$. Their adaptation to international cultural and normative principles-especially those that are propagated by various UN bodies and agencies-has contributed to the worldwide diffusion of ideas and isomorphism of nation states and social organizations [30,31]. The learning by nation states from their international social environment [32], the institutional interplay between nation states and international agencies in various international interaction environments [33], and, in particular, membership in international organizations [34], have all led to increasing national compliance with international treaties. In many cases, nation states have complied with international regulations, not just due to an instrumental calculation of the potential benefits for the nation; rather, they want to be a good member of world society and avoid deviant behavior in the international community. Furthermore, the linkage to international belief systems has contributed to stabilizing and legitimizing a political and social order within the domestic context, since international organizations usually represent "interestless others" [35] and they have a higher degree of legitimate authority than national and subnational actors [36].

This article brings the ideational level of communication within the Chinese social policy arena into focus. Concurrently, it reveals that national expression, narration, and condensation of ideas and scripts have been closely linked to the global level of normative and cognitive structure in social policy. Chinese social policy experts have proactively borrowed and used international examples to construct a legitimating framework for social policy reform. This article seeks to reveal the ideational and cognitive background of rapid social policy transformation in China, through uncovering two different sustainability approaches, illuminating how and why social policy has expanded over the last two decades and elaborating the ideational sources behind such expansion.

\section{Research Methods}

This research focuses on discourses regarding the "sustainability approach" and social policy development in China since the 1990s, especially in the postmillennial age. This study has applied the research method of documentary analysis, tracing discourses and interpretations of the nexus between sustainability and social policy in China. The dataset relies upon the analysis of various kinds of documents-including reports, guidelines, secondary literature, and other forms of written scripts concerning sustainability and social policy development in China. Some national-level reports that were proposed by the State Council (SC) and the National Development and Reform Commission (NDRC) have been incorporated into the research, for instance, "China's Sustainable Development Agenda in the Early 21st Century"—initiated by the State Council [37]—and the "National Report on Sustainable Development of the People's Republic of China" — created by the NDRC [38]. Reports on the evaluation of and recommendations for sustainable development in China that were provided by international organizations such as the OECD (Organization for Economic Co-operation and Development) and the UNFPA (United Nations Population Fund) are additionally included in the analysis. Through in-depth analysis of documents from Chinese academia, Chinese governments, 
and international governmental organizations, the discourses and interpretative narratives of Chinese actors and international agencies on sustainability and social policy have been reconstructed.

\section{Two Different Sustainability Approaches and Social Policy Development in China}

In the period between China's adoption of economic reforms and the millennium, social policy in China was situated in a critical state and precarious condition. The old labor insurance model that was inherited from the Maoist age had collapsed in the rapid reform process that moved towards a market economy. Rapid state retrenchment, diminishing social expenditures, and a shift in welfare responsibilities towards individuals and market mechanisms characterize social policy in this period. In the 1990s, the Chinese government started to tentatively explore and experiment with a few local pilot projects to establish social insurance programs and the Minimum Living Standard Scheme (MLSS), an analog to social assistance in OECD countries. On the threshold of the third millennium, China established an embryonic form of the modern welfare state: some social insurance branches had been created-such as old age pension insurance, health insurance, and eventually unemployment insurance, in 1999. These social insurance programs were only confined to employees in urban enterprises and the formal economic sector, which constituted the minority population in China. For instance, in 2000, old age pension insurance only covered 136 million employees, and health insurance only 37 million [39]. A national MLSS had been launched; however, it was confined to urban residents. China was still far from establishing a comprehensive social safety net for all of its residents.

Since the millennium, the restrained and cautious course of social policy that is shaped by neoliberal ideology in China has been incrementally substituted by an extensive and expansive course of social policy development. Since Hu and Wen came to power, a welfare-oriented policy was promoted by this self-proclaimed "people-centered" government (qinmin zhengfu). China has adopted an expansion course for social policy, accelerating social expenditures and public investments in social protection at a rapid pace, especially since the outbreak of the global financial crisis. In the field of old age pension insurance, China has combined a contribution-financed social insurance program for employees with a non-contributory basic pension for unprotected rural and urban residents, extending coverage from a privileged minority (employees in the formal sector) to the previously unprotected majority of the population. According to data from the Ministry of Human Resources and Social Security (MHRSS), in 2018 different old age pension programs covered 940 million people [40]. In the field of health insurance, the Chinese government has launched different types of health insurance for residents with non-employee status, covering nearly all previously uninsured urban and rural residents. After a steady expansion of more than a decade, the Chinese health insurance program has achieved quasi-universalism. According to the MHRSS, different health insurance programs nearly covered 1.35 billion people in 2018 [41]. Other social insurance branches-such as unemployment insurance and work accident insurance-have not undergone such expansive development; however, the number of insured people has also gradually increased in the last two decades. Further, the urban social assistance program-MLSS-has been fully transferred to rural areas, with a rural MLSS being created in 2007 [42]. According to Liu and Sun, China is the only country in the Global South that has created a social assistance program that is similar to OECD countries [43].

\subsection{The Traditional Sustainability Approach: How can Social Policy Development be Sustainable?}

Social policy (in Mandarin: shehui zhengce) in the Chinese socio-linguistic context is usually termed shehui baozhang (social security or social protection). It has gradually appeared on the surface of the Chinese public discourse space over the course of Chinese economic reform. In the mid-1980s, while facing the grand economic transformation and the shifting role of state-owned enterprises (SOEs), the Maoist model of labor protection and labor insurance (laodong baoxian) had substantially eroded. Against this backdrop, some pioneering Chinese scholars who had travelled to Western countries and received a Western education called for importing a new model of "social security" into China. During this episode, China started to approach the Western model of social policy and the welfare 
state [44]; knowledge and practices from Western welfare states were intensively studied and absorbed by Chinese scholars and officials and new knowledge and skills regarding social policy were imported.

During the first encounter between China and the West in the field of social policy, some influential Western welfare states-like United Kingdom and the United States-initiated the promotion of welfare state retrenchment, restraining public expenditures, and diminishing the role of the welfare state [45-47]. With the worldwide diffusion of neoliberalism, some scholars from Western welfare states started to rethink and even query the model of the welfare state in the postwar era, advocating more self-responsibility and the integration of market mechanisms into the field of social protection. Shaped by this new development trend in the world's social policy in the 1980s and 1990s, the first large-scale learning from Western welfare states by Chinese social policy experts has inevitably exhibited a character of duality. On the one hand, Chinese social policy scholars were cognizant of a social insurance model, labeled the Bismarck model, spreading worldwide [44]; on the other hand, they recognized that the clout of the narrative of privatization and capital funded system was rising around the globe [48].

Shaped by these two narratives in Western welfare democracies-additionally being influenced by economic reforms oriented towards a market economy-the "sustainability approach" within social policy has become popularized in the Chinese knowledge market, being closely linked to the narrative of the market economy. This sustainability approach, which emerged in the early 1990s, can be considered to be an "old" version, which can be differentiated from the "new" approach that also appeared in the 1990s, but only became publicly visible and influential since the millennium. This article argues that these two types of sustainability approach have coexisted and constituted two influential discourses within the Chinese social policy arena.

The first version of the sustainability approach in the field of social policy recognized the basic fact that China needed to launch a modern social protection system that is similar to Western market economies and that, in particular, China ought to establish a contribution-related social insurance program. In parallel, the design of social insurance and other social protection programs was closely linked to the approach of fiscal affordability. The core questions concerned whether the social security programs were reliable and-from a long-term perspective-financeable, and also which standard of benefit level should be adopted in the Chinese context. As in the case of most OECD countries, the demography factor played a significant role in constructing the sustainability approach in China. Drastic demographic transformation and population aging-as well as the rapid decline in birth rates-hollowed out the functional basis for public social insurance, especially in the field of old age pension insurance. The demographic factor constituted the starting point for the reform of social insurance programs that were financed by the pay-as-you-go model (PAYGO), favoring discourses regarding a capital funded system.

In the 1990s, Chinese authorities piloted various local policy experiments on old age pension insurance and then created a hybrid model of old age protection, combining a public pension system pillar and a capital funded pension pillar. China endeavored to find a "middle way" between the public pension model and the privatizing pension model. Meanwhile, narratives and discourses on the nexus between social policy and sustainability emerged within Chinese academia. The emphasis at that time was overwhelmingly placed on old age pension insurance and its sustainable development. Scholars, local officials, and practitioners tentatively investigated how the Chinese pension system could be financially feasible and affordable [49-51].

Chinese scholars who continue to adhere to the market-oriented approach-which is commonly labeled as the "pro-market school" (the so-called shichangpai)—have given a special research priority to the area of sustainable development in the old age pension scheme. Some of them are economists and financial experts, and some are social scientists that are enthusiastic about the financial study of the old age pension system. The latter have made earnest efforts in the actuarial and mathematic study of different scenarios of the potential development of pension expenditures and pension debts in China over the upcoming decades; they include scholars, for instance, from the Center for International 
Social Security Studies (CISSS) of the Chinese Academy of Social Sciences (CASS). These studies-as well as discourses regarding the fiscal sustainability of social insurance programs-have maintained a certain degree of visibility and clout since the millennium, many of them being connected to international experiences and trends from OECD countries, such as the United Kingdom, Italy, the Nordic countries, and Mediterranean nations. They have reached the conclusion that too-rapid increases in pension expenditures have made public finance unsustainable and heavily undermined the fiscal balance between revenues and expenditures in Western welfare states. Such studies regularly use a set of indicators to measure the "sustainability" or "unsustainability" of the public pension system-such as the level of generosity, the level of benefits, and the level of replacement rate-not only in the old age pension system, but also in other social insurance programs. According to Zheng-a renowned pension scholar from the "pro-market school"- too generous a pension system and too high a replacement rate in Italy have exacerbated its financial unsustainability tremendously and, additionally, too high pension insurance contributions have exerted great pressure on the Italian labor market [52]. The economist Gong Chen has delved into different pension reforms in the postwar era in the United Kingdom and has argued that, according to British experiences and lessons, China should establish a simplified, affordable, and sustainable pension system that strengthens self-responsibility. Moreover, this system should correspond to China's particular national conditions (zhongguoguoging); in other words, China-as a developing country—should only create a moderate pension system with a moderate benefit level. A high-level pension system is not adaptable to China [53]. Since the global financial crisis and, in particular, since the European debt crisis, some Chinese scholars from economic and financial circles—along with some "pro-market scholars"—-have intentionally linked these crises to social policy and prematurely attributed these currency and fiscal crises to excessive high social expenditures and excessively generous social protection programs [54,55]. However, adjective prefixes, like "too high" or "too generous", are subjectively constructed rhetoric. Whether a social policy program is too generous or too "luxurious" for one state depends on the social construction of "rationality" and the definition of mainstream opinions among social elites.

In 2011, the CISSS issued the "China Pension Report 2011" (CPR 2011) [56], which systematically responded to the European debt crisis and the lessons from European welfare states and pension systems. Several scholars from CISSS have recommended this new book in the Chinese newspaper "China Securities Journal" and linked this report to the issue of sustainability of the old age pension system:

The European sovereign debt crisis has once again triggered a high level of attention to the pension system. Excessive welfare treatment in Greece has become one of the culprits of the debt crisis. Nearly half of the EU's conditions for aiding Greece involve cutting welfare and lowering pensions. The Greek event has sounded the alarm for European and even worldwide pensions, and it has also inspired the reform of the Chinese pension system.

On December 20, the "China Pension Development Report 2011" prepared by the CISSS of the CASS was officially released. The first International Social Security Forum hosted by the CASS was held on the same day. Hua Jianmin, vice chair of the Standing Committee of the National People's Congress, proposed at the meeting that "we shall treat the sustainability of the pension system as the primary agenda". We must have a sense of urgency and look at the long-term and sustainability of our pension system with a cautious attitude. "Sustainability" is the primary problem facing the pension system of all countries with an aging population.

$\cdots$

In the European debt crisis, the welfare system-including the pension system-is one of its important incentives. The generous social security has overwhelmed the welfare state. The constant explicitization and monetization of "aging costs" has increasingly become an important incentive for the European debt crisis, and the welfare state has gradually fallen into a debt quagmire. In the context 
of the global financial crisis and even the European debt crisis, the reform of social security systems in various countries has been surging, which also provides an opportunity for China to re-examine the sustainability of the pension system.

From the level of welfare expenditure, in the past 50 years, the proportion of social expenditure to GDP in EU countries has increased by one percentage point every 10 years; from the perspective of pension benefits, in 2010, the average replacement rate of pensions in OECD countries was 57 percent. In the United States, only 39 percent, and Greece 95.7 percent... These figures show that the excessive pension treatment in European welfare states affects the sustainability of economic and social development. [57]

In this essay, pro-market scholars attributed the outbreak and deterioration of the European debt crisis to the excessive European welfare system and, in particular, to the "generous" and "excessive" Greek pension system. However, the European debt crisis has been driven by multiple and complex causes that are related to various areas-such as the economic, fiscal, public, and currency-related policy of the different EU-member states and of the supranational entity, the European Union. Social policy is only one part of the highly complex causal logic chains in the European crisis; there are no sound and reliable arguments that can convincingly substantiate that the European welfare system is the exclusive cause in triggering this crisis. The interweaving of the pension systems of the European Union (with a focus on Greece) and the European debt crisis is based on belief rather than facts.

This approach of sustainability-highlighting the persistent, continuous, and enduring development of old age pensions and other social protection programs-is inclined to judge these programs from an economic, fiscal, and monetary perspective, indirectly legitimating modest development and growth for social policy in China, which—in their view-corresponds to economic strength, fiscal capacity, and, particularly, to the developing-country status of China. The advocacy coalition for this approach usually consists of economists, financial experts, and social science scholars carrying a strong tendency towards market-related development logic. They place great emphasis on the affordability and adequacy of social policy programs, which should set up a low or moderate level of benefits, arguing that a generous social policy program is detrimental to Chinese economic development and public finance. Moreover, they tend to incorporate market mechanisms into social policy programs, favoring fully funded or partially funded programs, for instance, regarding the old age pension plan. According to their views, the adoption of market mechanisms and the strengthening of self-responsibility are conducive to the sustainability of social policy programs.

\subsection{The New Sustainability Approach: Creating the Nexus between Social Policy and Sustainable Social Development}

The emergence of a sustainability approach that is based on a balanced development model goes back to the early 1990s in China; initially, it closely dovetailed with environmental and ecological issues, for instance, environmental protection. In 1994, two years after the United Nations Conference on Environment and Development in Rio de Janeiro (1992), the Chinese government issued a national report entitled “China's Agenda 21: A White Paper on China's Population, Environment and Development in the 21 Century" [58]. This report included 20 chapters and it established a national target for sustainable development through the declaration and self-proclamation of development goals and concrete action programs by the Chinese state. Several areas constituted the crux of this report-including demographic development, sustainable economic development, education, and the sustainable development of agriculture and industry. The center of gravity was placed on environmental and ecological issues-such as environmental protection, the conservation of natural resources and their sustainable use, biodiversity conservation, protection of the atmosphere, and control of greenhouse gas emissions. In this report, social issues are only mentioned in passing, and social protection, social policy, and social welfare did not even appear in this report. Although this report incorporated the field of hygiene and health into the agenda, this field had little to do 
with social protection and social policy as such. In this case, it only related to epidemiological and diseases-related narratives-such as the control of infectious diseases and reducing the incidence rate of disease, reducing health damage that is caused by environmental pollution, and improvement of water and sanitation infrastructure [58]. Accompanied by the emergence of narratives on sustainable development at the national level in the mid-1990s in China, the economic, ecological, environmental, and demographic objectives were firstly included in national plans and action programs, while social welfare and social policy remained invisible in the national narrative on sustainability.

Throughout the 1990s, social problems that are caused by deficient social protection became apparent all over China-including the soaring level of industrial accidents and occupational diseases, and rapidly increasing unemployment in an increasingly marketized labor market. The privatization of education and medical services through market economic reform and the lack of old age protection programs became the most important concerns for the Chinse public. The low-level development of social protection, overshadowed by a state developmentalism policy based on a belief in economic primacy jeopardized the legitimacy of Chinese authorities. Against this backdrop, Chinese governments at different levels initiated some local pilot projects, creating a tentative social insurance framework for various insurance branches in the 1990s-including old age pension insurance and medical insurance for urban employees, and unemployment insurance for the urban formal sector. A national social assistance program - the Minimum Living Standard Scheme (MLSS)—was launched in 1999 in urban areas. At the threshold of the new millennium, the social consciousness and the problem awareness of poverty and social protection were remarkably elevated, and the further development of the Chinese sustainability approach reflected this new change.

The landmark event for a new sustainability approach was the adoption of the "China Sustainable Development Agenda in the Early 21 Century", which was issued by the State Council of China in 2003. This agenda innovatively included "social security" into an action program at the national level. Section 2 of this report was related to guiding principles and development objectives that would establish a comprehensive social security system and fulfill a development objective, in which all Chinese people shared social security [37]. Unlike the social protection programs before 2003-within which urban employees in formal employment sectors and urban residents were the main targets of social safety net programs-this report on sustainability explicitly proposed that all Chinese residents should be covered by social security programs. The extension of the target audience and the recipients of welfare benefits demonstrated that China was seeking to achieve universal coverage, symbolizing a welfare state effort to care for the wellbeing of the whole nation. Besides the section narrating the overarching target, this report elaborated on the significance of social security in national sustainable development in detail. Part III of this report was related to core areas of sustainable development and Section 2 of this part focused upon social development within a sustainability narrative, highlighting social security in particular. According to the agenda, an independent social security system-operated and managed beyond the level of enterprises and public institutions-was considered to be a development priority for Chinese social policy. Besides the regular old age pension insurance and medical insurance, unemployment insurance, work accident insurance, and maternity insurance would be additionally promoted. Another target of this section was to facilitate the MLSS systems and social welfare, as well as community welfare programs for elderly people. This sustainable development agenda (2003) included nearly all of the integral parts of modern social policy within the welfare state framework-social insurance, social assistance, and social welfare, with a focus on local social services [37]. Moreover, according to the 2003 agenda, China should seek to establish a rural old age pension program, a rural medial insurance system, and a rural Minimum Living Standard Scheme [37]. This agenda symbolically set a development goal for the three social insurance programs-the old age pension, health protection, and the social assistance program (the MLSS) - suggesting that they should become national and universal social protection programs, transcending the narrow scope of urban areas and groups with employee status. 
This state document—which was issued by a high-level department (the State Council)—made social policy part of Chinese sustainable development, resulting in a historic turning point at which the significance of social security in socio-economic modernization was explicitly acknowledged and the status of this policy arena was elevated to a priority for state development targets. Unlike in the 1990s, a previously invisible policy arena had now achieved a central place in the long-term development goals for China. Since the adoption of the sustainable development agenda in 2003, this new sustainability narrative that integrates the arena of social security into Chinese sustainable development has become prevalent and rapidly grown into a popular approach among Chinese think tanks, research institutes, and epistemic communities. A group of natural science scholars from the Institute of Geographic Sciences and Natural Resources Research (IGSNRR) of the Chinese Academy of Sciences (CAS) co-published an article in 2008 illuminating the sustainable state and trends in Chinese development from the perspective of natural resources. The focus was not only narrowed to areas, such as the environmental system, energy consumption, and a green development model; it surprisingly grappled with issues of social development with explicit reference to social policy. In Part IV—entitled "The Sustainability of Social Development" - social security was formulated as a "problem field", since the narrow degree of coverage in social protection programs and the gap in social security between rural and urban areas overshadowed the fulfillment of the objective of social sustainability [59]. According to the IGSNRR scholars, even though Chinese social security had begun to take shape, the coverage of urban workers' pension and health insurance was less than 45 percent and 42 percent, respectively, and rural residents-who accounted for 60 percent of the total population-were basically excluded [59]. They additionally expressed their concerns over the impediments to expansion of social security to all residents [59].

The formation of social problems and crisis awareness regarding issues of social development-and especially social policy and social security-have been continually linked to a repetitive emphasis on the relevance and significance of social security in sustainable development over the course of the transformation of the socio-economic development model. Since the millennium, China has gradually begun to transform itself from a low-income country to a middle- and even an upper-middle-income country. In response, many scholars have suggested that China must increase its public investment in social security and a social safety net in order to raise human capital, boost domestic demands, reduce export dependence on overseas markets-especially on the fluctuating global market-and increase the domestic market and internal purchasing power to benefit long-term development $[60,61]$. According to Liu, as soon as a nationwide full-scale old age pension insurance and health insurance that covers the entire population would be launched in China, these social security programs would act as an "accelerating stimulator", which would boost the bleak domestic consumer market for the coming decades, since one of the notable barriers to domestic consumption is the lack of old age pension insurance and medical insurance, along with the lack of a feeling of security among the majority of the Chinese population [61]. Thus, increasing public investment in social security has been interpreted as a crucial factor in the country's enduring economic rise.

In 2012, the National Development and Reform Commission (NDRC) published the "People's Republic of China National Report on Sustainable Development", which is another major report on sustainable development at the national level in post-millennium China. In the first chapter-entitled "General Introduction" - the "accelerating construction of the social security system covering urban and rural residents" was narrated as one of the key areas for sustainable social development, along with "free and compulsory education", "medical protection and medical services", and "protection of women's and children's rights" [38]. In Section 4, which concretely introduced core areas of sustainable development, the social security system was reified in detail:

A sound social security system is of great significance for achieving sustainable social development. With the continuous development of the economy and society, and the steady growth of the total population, China is paying more and more attention to the construction of the social security system, and clearly proposes to adhere to the principle of broad coverage, basic protection, multi-level and 
sustainable growth, accelerating the promotion of a social security system covering urban and rural residents and steadily improving the level of protection.

In the past ten years, the government has continuously improved the urban and rural basic old-age security system and the basic medical security system, and strived to achieve full coverage for urban and rural residents. The government has accelerated the construction of unemployment insurance, work injury insurance, and the maternity insurance system, and focused on building a social assistance system. The government has promoted social welfare, moving it towards a universal inclusive system, and it has improved the disaster relief system, established and improved the rescue system for vagrants and beggars, and guaranteed and provided important institutional support for improving people's livelihoods. [38]

Further, this report introduced the laws and decrees that were enacted in the arena of social security, the development of the degree of coverage, and the benefit level of various social security programs over the past ten years. The national report in 2012 stressed the key objectives that were set up in the agenda in 2003-such as universal coverage for all residents; moreover, this rhetoric of universalism was linked to a model of inclusive growth that would benefit different social groups in China.

\subsection{Domestic Discourses Shaped by the Cosmopolitan World Community}

Both the old and the new sustainability approaches have been deeply shaped by the international environment and the discourses that are articulated by international agencies. In the traditional version of the sustainability approach on affordable and financeable social insurance programs, a group of Chinese academia - the pro-market scholars - has steadily borrowed international examples and lessons to justify moderate and adequate social insurance in China. Not only examples of Western welfare states, but also austerity policies that were adopted after the European debt crisis have been used by pro-market groups as selected experiences to remind Chinese policy makers of the negative consequences of a generous welfare state. Greece has been usually stereotyped as an extreme negative example, making the Chinese public and elite circles more vigilant regarding expanding social expenditures. An emerging global observation and comparison horizon-incorporating rich experiences from the Global North-has served as an "ideational weapon" for Chinese economists, financial experts, and social scholars with neoliberal tendencies for propagating their sustainable model of social policy.

Another sustainability approach for China's socio-economic development is even more closely related to the emerging world culture of sustainability that is promoted by $\mathrm{UN}$ agencies and affiliates. The birth of a Chinese national narrative on sustainable socio-economic development has directly emerged against the backdrop of the United Nations Conference on Environment and Development in 1992 in Rio de Janeiro. The agendas, principles, and guidelines that were proposed by UN entities and other international organizations have elicited strong national concern over sustainable development in China, substantially helping policymakers in formulating and setting up a futuristic version of a development model. Increasingly integrating into the international community and becoming an integral part and member state of more international governmental organizations, China has increasingly located its national image in an international social environment, paying close attention to its international expression and the formulation of ideas and concepts. Responsiveness to cosmopolitan world guidelines and interaction with the international community have strongly shaped the behavior of the Chinese state. The principles and guidelines from the outside world have been reflected in national programs and agendas, being socialized as a member of the cosmopolitan world community [62].

International actors have recurrently linked the social security narrative to the sustainability model. In 2013, OECD initiated a report with the title "China: Speeding Up the Pace of Reform and Promoting a Green and Inclusive Growth", proposing concrete policy recommendations to the Chinese 
government. Several policy recommendations were related to old age pension insurance and health insurance, and the OECD called for the central government to assume more responsibility for old age expenditures in rural areas. Further, the OECD touched upon a particular technical issue in social security, suggesting that China enhance coverage by the old age pension and health insurance for the migrant population and solve the issue regarding the portability of social security-a new dimension of Chinese social policy [63]. In 2017, the ILO introduced its report- “World Social Protection Report 2017-19" - and presented the development of Chinese social security, emphasizing the significance of mitigating poverty, reducing social inequality, promoting economic growth and social justice, and fulfilling Sustainable Development Goals (SDGs). The ILO expert Nuno Cunha stated: "The Chinese experience is highlighted in the new World Social Protection Report as a good example that showcases how it is possible to extend pension and health care coverage to citizens over a relatively short period of time through a combination of contributory and non-contributory schemes" [64]. In 2018, the Representative Office of the United Nations Population Fund (UNFPA) initiated a brief bulletin entitled "Fair and Health Ageing: Promote China's Sustainable Development". In this bulletin, the UNFPA called upon the Chinese government to further invest in social security and expand the coverage of old age pension insurance. Further, the UNFPA proposed granting additional old age allowances to the rural elderly, so that their income could at least reach the same level of the Minimum Living Standard Scheme as in urban areas and they would no longer need to work in retirement age [65].

\section{Conclusions}

With the development, evolution, and incremental expansion of social policy in China over the past decades, two different "sustainability approaches" have emerged. The old, traditional version of the sustainability approach is preoccupied with the economic, financial, and numerical dimensions of discourses, highlighting the affordability of social insurance programs and the adequacy of the rational benefit levels, which would prevent the country from falling into a welfare trap, in this case, an excessively generous welfare system exceeding national economic strength and fiscal capacity. The preferred research methods of pro-market scholars are quantitative, which place great emphasis on the mathematical and actuarial study of the development of revenues, expenditures, and the public financial burden of social insurance programs in the coming decades. Pro-market scholars and communities have used the austerity policy of the European Union after the debt crisis as a global lesson that renders their modest social policy investment model convincing and striking. Stereotyped as a negative example and a "failing" state, the Greek social welfare system serves as an argument for pro-market scholars to strengthen their sustainability approach —an austere social policy concept that avoids the high-welfare trap and will ostensibly be fiscally sustainable.

Another sustainability approach that can be labeled as holistic sustainability of society has appeared in Chinese interaction and communication with the international community [66], based on an environment-centered sustainability model. This new version has included social security and social protection into the narrative of sustainability since the millennium. Social policy constitutes an integral ingredient of sustainable social development, one of the three primary and overarching objectives of a sustainable development model, in addition to the economy and ecology. From this angle, social policy is no longer judged from the monetary and fiscal perspective; rather, it has been re-defined as a "stabilizing anchor" that serves to guarantee enduring, perpetuating, and sound development in China from a long-term perspective. According to the views of Chinese social policy experts, a comprehensive social safety net is conducive in boosting domestic consumer demand and stimulating the potentially largest domestic market in the world. Increasing social expenditures and public finance will contribute to the current transformation of China's development model from a labor-intensive to a knowledge- and know-how-intensive new economy, favoring the sustainable economic rise of China. Social policy has not only functionally served to fulfill the grand purpose of sustainability; it has also melted into an inextricable part of the holistic target of a sustainable development model for Chinese society. 
Comparing these two sustainability approaches reveals that both narratives emphasize the different dimensions of social policy. The old version of the sustainability approach is closely linked to demographic and financial policy, focusing on the issue of demographic aging and fiscal burdens engendered through steady and extended public investment in social protection. Although this approach never clearly refutes the universal coverage of social insurance programs, it has indirectly incited passive and cautious thinking emphasizing the "welfare syndrome" created by the high spending and the benefit levels of social policy. As a result, a de facto tempering social policy model-corresponding to a tempering fiscal policy—has been advocated by a group of economists, financial experts, and pro-market scholars, as well as their think tanks (see Table 1). In contrast, the new sustainability approach is linked to a broad sense of economic, ecological, and social development, with an internalized core belief in the essential value of social policy for the comprehensive development and the transformation of a society. It focuses on the significant role of social policy in the promotion of human capital, stimulating the domestic consumer market, and guaranteeing sound, long-term, and consistent development. This narrative has greatly benefited an expanding social policy model and has provided legitimate sources for the universal coverage of social protection programs in China. Different state ministries, public institutions, and international organizations advocate for this model (see Table 1). Since the millennium, the clout of the new sustainability approach has rapidly increased. One of the most influential state departments-the State Council—has elevated it to national policy, and this discourse has exerted far-reaching influence on the expansion of social policy in China. However, the old sustainability approach remains a powerful discourse. Pro-market scholars still make an appeal to calm down the "great leap forward" of Chinese social policy and restrain the growth of benefit levels. The development of Chinese social policy in the future will be steadily influenced by these two discourses and logics in sustainability.

Table 1. Two Sustainability Approaches and their Impingements on the Social Policy Model in China.

\begin{tabular}{|c|c|c|}
\hline & $\begin{array}{l}\text { Sustainability Approach I } \\
\text { (Fiscal Sustainability) }\end{array}$ & $\begin{array}{l}\text { Sustainability Approach II (Holistic } \\
\text { Sustainability of Society) }\end{array}$ \\
\hline Major concern central & $\begin{array}{l}\text { Affordability of social policy, adequate } \\
\text { benefits, generosity }\end{array}$ & $\begin{array}{l}\text { Social policy as core value and feature of } \\
\text { sustainable development }\end{array}$ \\
\hline Interrelated areas & Demography, economy, finance & $\begin{array}{l}\text { Economic, social, and ecological } \\
\text { development in a broad sense }\end{array}$ \\
\hline Impingement on social policy & A model for tempering social policy & $\begin{array}{l}\text { A model for expanding social policy, } \\
\text { universal coverage, social inclusion }\end{array}$ \\
\hline Actors and agencies & $\begin{array}{l}\text { Economists, financial experts, social } \\
\text { scholars of the pro-market school, } \\
\text { think tanks }\end{array}$ & $\begin{array}{l}\text { Social policy scholars, think tanks, } \\
\text { high-level state departments and ministries }\end{array}$ \\
\hline Related documents & $\begin{array}{l}\text { Economic and financial studies on } \\
\text { affordability of social policy }\end{array}$ & $\begin{array}{l}\text { State reports on sustainability and social } \\
\text { policy, legal documents like the social } \\
\text { insurance law of } 2010\end{array}$ \\
\hline International reference & $\begin{array}{l}\text { Lessons from welfare states with a } \\
\text { high level of social expenditures }\end{array}$ & $\begin{array}{l}\text { International ideas and principles on } \\
\text { sustainability and social policy }\end{array}$ \\
\hline
\end{tabular}

Source: Authors' own compilation.

Author Contributions: Conceptualization, T.L.; Data curation, T.L., Y.L. and T.T.; Formal analysis, T.L., Y.L. and T.T.; Investigation, T.L., Y.L. and T.T.; Writing—original draft, T.L.; Writing—review \& editing, Y.L. and T.T.

Funding: This research is funded by the Deutsche Forschungsgemeinschaft (DFG, German Research Foundation)—Projektnummer 374666841-SFB 1342.

Acknowledgments: This article stems from the research project “Dynamics of Chinese Social Policy: The Interplay of National and International Influences". The project is part of the new Collaborative Research Center (SFB) 1342 "Global Dynamics of Social Policy" at the University of Bremen, funded by the German Research Foundation DFG (see www.socialpolicydynamics.de). The authors are additionally indebted to three anonymous reviewers for valuable suggestions given to an earlier draft of this article.

Conflicts of Interest: The authors declare no conflict of interest. 


\section{References}

1. International Social Security Association (ISSA). Government of China Receives International Social Security Award. 2016. Available online: https://www.issa.int/en_GB/-/government-of-china-receivesinternational-social-security-award (accessed on 10 January 2019).

2. Bolognesi, T. The results of modernizing network industries: The case of urban water services in Europe. Compet. Regul. Netw. Ind. 2014, 15, 306-333. [CrossRef]

3. Bolognesi, T. Modernization and Urban Water Governance: Organizational Change and Sustainability in Europe; Palgrave Macmillan: London, UK, 2018.

4. Whiteford, P. From enterprise protection to social protection: Pension reform in China. Glob. Soc. Policy 2003, 3, 45-77. [CrossRef]

5. Leung, J.C. The emergence of social assistance in China. Int. J. Soc. Welf. 2006, 15, 188-198. [CrossRef]

6. Deacon, B. Global Social Policy: International Organizations and the Future of Welfare; Sage Publication: London, UK, 1997.

7. Bearce, D.H.; Bondanella, S. Intergovernmental organizations, socialization, and member-state interest convergence. Int. Organ. 2007, 61, 703-733. [CrossRef]

8. Cox, R. The path-dependency of an idea: Why Scandinavian welfare states remain distinct. Soc. Policy Adm. 2004, 38, 204-219. [CrossRef]

9. Taylor-Gooby, P. Ideas and Welfare State Reform in Western Europe; Palgrave Macmillan: Basingstoke, UK, 2005.

10. Lessenich, S. Wohlfahrtsstaatliche Grundbegriffe: Historische und Aktuelle Diskurse; Campus Verlag: Frankfurt am Main, Germany, 2003.

11. Kaufmann, F.X. Variations of the Welfare State: Great Britain, Sweden, France and Germany between Capitalism and Socialism; Springer: Berlin, Germany, 2013.

12. Parsons, T. The Social System; Routledge \& Kegan Paul: London, UK, 1967.

13. Haas, P.M. Introduction: Epistemic communities and international policy coordination. Int. Organ. 1992, 46, 1-35. [CrossRef]

14. Sabatier, P.A. An advocacy coalition framework of policy change and the role of policy-oriented learning therein. Policy Sci. 1988, 21, 129-168. [CrossRef]

15. Jenkins-Smith, H.C.; Nohrstedt, D.; Weible, C.M.; Ingold, K. The advocacy coalition framework. In Theories of the Policy Process, 4th ed.; Weible, C.M., Sabatier, P.A., Eds.; Westview Press: Boulder, CO, USA, 2017; pp. 135-171.

16. Weible, C.M.; Cairney, P. Practical lessons from policy theories. Policy Politics 2018, 46, 183-197. [CrossRef]

17. Zito, A.R. Epistemic communities, collective entrepreneurship and European integration. J. Eur. Public Policy 2001, 8, 585-603. [CrossRef]

18. Yeates, N. Social politics and policy in an era of globalization: Critical reflections. Soc. Policy Adm. 1999, 33, 372-393. [CrossRef]

19. Liu, T. Occupational safety and health as a global challenge: From transnational social movements to a world social policy. Transnatl. Soc. Rev. 2018, 8, 50-63. [CrossRef]

20. Holzmann, R. Global pension systems and their reform: Worldwide drivers, trends and challenges. Int. Soc. Secur. Rev. 2013, 66, 1-29. [CrossRef]

21. Cerami, A.; Vanhuysse, P. Post-Communist Welfare Pathways: Theorizing Social Policy Transformations in Central and Eastern Europe; Palgrave Macmillan: Basingstoke, UK, 2009.

22. Deacon, B. Global Social Policy and Governance; Sage Publications: London, UK, 2007.

23. Kaasch, A. Contesting contestation: Global social policy prescriptions on pensions and health systems. Glob. Soc. Policy 2013, 13, 45-65. [CrossRef]

24. Liu, T. Globale Wissensdiffusion in der Politik Sozialer Sicherung: Die Einführung einer Gesetzlichen Unfallversicherung in der Volksrepublik China; PL Academic Research: Frankfurt am Main, Germany, 2015.

25. Leisering, L.; Liu, T. Globale Wissensdiffusion in der Sozialpolitik. Z. Soz. 2010, 56, 173-206. [CrossRef]

26. Weyland, K. Theories of policy diffusion lessons from Latin American pension reform. World Politics 2005, 57, 262-295. [CrossRef]

27. Sugiyama, N.B. The diffusion of conditional cash transfer programs in the Americas. Glob. Soc. Policy 2011, 11, 250-278. [CrossRef] 
28. Goodman, R.; Jinks, D. Socializing States: Promoting Human Rights through International Law; Oxford University Press: Oxford, UK, 2013.

29. Kelley, J. International actors on the domestic scene: Membership conditionality and socialization by international institutions. Int. Organ. 2004, 58, 425-457. [CrossRef]

30. Meyer, J.W.; Boli, J.; Thomas, G.M.; Ramirez, F.O. World society and the nation-state. Am. J. Sociol. 1997, 103, 144-181. [CrossRef]

31. Powell, W.W.; DiMaggio, P.J. (Eds.) The New Institutionalism in Organizational Analysis; University of Chicago Press: Chicago, IL, USA, 2012.

32. Schimmelfennig, F. International socialization in the new Europe: Rational action in an institutional environment. Eur. J. Int. Relat. 2000, 6, 109-139. [CrossRef]

33. Haas, E.B. Beyond the Nation State: Functionalism and International Organization; Stanford University Press: Stanford, CA, USA, 2008.

34. Frank, D.J. The social bases of environmental treaty ratification, 1900-1990. Sociol. Inq. 1999, 69, 523-550. [CrossRef]

35. Meyer, J.W. The changing cultural content of the nation-state: A world society perspective. In State/Culture: State-Formation after the Cultural Turn; Steinmetz, G., Ed.; Cornell University Press: Ithaca, NY, USA; New York, NY, USA, 1999; pp. 123-143.

36. Meyer, J.W.; Rowan, B. Institutionalized organizations: Formal structure as myth and ceremony. Am. J. Sociol. 1977, 83, 340-363. [CrossRef]

37. State Council of the PRC. China's Sustainable Development Agenda in the Early 21st Century; China Environmental Science Press: Beijing, China, 2004.

38. National Development and Reform Commission of the PRC. National Report on Sustainable Development of the People's Republic of China; People's Publishing House: Beijing, China, 2012.

39. National Bureau of Statistics. China Statistical Yearbook: Basic Situation of Social Security. 2018. Available online: http:/ / www.stats.gov.cn/tjsj/ndsj/2018/indexch.htm (accessed on 10 January 2019).

40. Ministry of Human Resources and Social Security (MHRSS). The Accumulated Surplus of Basic Pension Insurance Funds for Employees Reached Nearly 5 Trillion Yuan in 2018. 2019. Available online: http:/ /www. xinhuanet.com/fortune/2019-01/16/c_1210039786.htm (accessed on 17 January 2019).

41. Ministry of Human Resources and Social Security (MHRSS). China's Basic Medical Insurance Covers More Than 1.35 Billion People. Available online: http:/ / politics.people.com.cn/n1/2018/1010/c1001-30331787. html (accessed on 17 January 2019).

42. Chan, C.K. Re-thinking the incrementalist thesis in China: A reflection on the development of the minimum standard of living scheme in urban and rural areas. J. Soc. Policy 2010, 39, 627-645. [CrossRef]

43. Liu, T.; Sun, L. Urban social assistance in China: Transnational diffusion and national interpretation. J. Curr. Chin. Aff. 2016, 45, 29-51. [CrossRef]

44. Zhou, H.; Zhang, J. Towards a Society with Social Protection for All. A Concise History of Social Security Transformation in Modern China; China Social Sciences Press: Beijing, China, 2015.

45. Pierson, P. Dismantling the Welfare State? Reagan, Thatcher and the Politics of Retrenchment; Cambridge University Press: Cambridge, UK, 1994.

46. Starke, P. The politics of welfare state retrenchment: A literature review. Soc. Policy Adm. 2006, 40, 104-120. [CrossRef]

47. Hacker, J.S. Privatizing risk without privatizing the welfare state: The hidden politics of social policy retrenchment in the United States. Am. Political Sci. Rev. 2004, 98, 243-260. [CrossRef]

48. Hu, A. The global spread of neoliberalism and China's pension reform since 1978. J. World Hist. 2012, 23, 609-638. [CrossRef]

49. Shi, W. The economic and financial impact of the existing pension system. China Econ. Inf. 1996, 5, 5-6.

50. Lu, Y. Thoughts on the sustainable development of old age pension insurance. Mark. Demogr. Anal. 1998, 4, $39-41$.

51. Lin, Z.J. Improve the social security system to fulfill the sustainable development of the social security work. Great Tide 1999, 2, 20-22.

52. Zheng, B.W.; Song, K. NDC: The pension reforms over the last decade in Italy. J. Eur. Stud. 2005, 22, 94-110.

53. Chen, G. Tropism of pension system reform: International experience and enlightenment. Reform 2009, 21, 110-115. 
54. Lu, D.A. Reflection on European debt crisis and welfare system. Reform Strategy 2012, 27, 21-22.

55. Xu, M.Q. Theoretical review and analysis on European debt crisis. Stud. Int. Financ. 2013, 29, $36-43$.

56. Centre for International Social Security Studies (CISSS). China Pension Report 2011; Economic Management Press: Beijing, China, 2011.

57. CISSS. Sustainability Is the First Proposition of China's Pension System. 2011. Available online: http://ilas. cass.cn/webpic/web/ilas/uploadfiles/cn/\%7BA8C7DF9A-D605-4B57-BD82-CE8D240554C7\%7D.pdf (accessed on 19 January 2019).

58. State Council of the PRC. China's Agenda 21: White Paper on China's Population, Environment and Development in the 21 Century; China Environmental Science Press: Beijing, China, 1994.

59. Institute of Geographic Sciences and Natural Resources Research (IGSNRR). Sustainability status and trends of China's development: An assessment based on the natural resource base. Resour. Sci. 2008, 30, 1349-1355.

60. Liu, T. China's Strategy of Rise. Investigation into a Chinese Strategy towards Revival with a Historic View and Global Perspective; Xinhua Publishing House: Beijing, China, 2007.

61. Liu, C. Research on the Role of Social Security in Promoting Social Harmony and Economic Growth. 2011. Available online: http:/ /www.chinareform.org.cn/society/ensure/Report/201106/t20110629_114393.htm (accessed on 19 January 2019).

62. Liu, T.; Leisering, L. Protecting injured workers: How global ideas of industrial accident insurance travelled to China. J. Chin. Gov. 2017, 2, 106-123. [CrossRef]

63. OECD. China: Speeding Up the Pace of Reform and Promoting a Green and Inclusive Growth. 2013. Available online: https:/ / www.oecd.org/general/OECD\%20china\%20brochure\%202013\%20in\%20chinese. pdf (accessed on 21 January 2019).

64. ILO. ILO's New Report Notes Chinese Progress on Social Protection. 2017. Available online: https:/ / www.ilo.org/beijing/information-resources/public-information/press-releases/WCMS_ 606868/lang--en/index.htm (accessed on 22 January 2019).

65. UNFPA. Fair and Health Ageing: Promote China's Sustainable Development. 2018. Available online: https:/ / china.unfpa.org/sites/default/files/pub-pdf/Chinese-UNFPA \%20China\%20policy\%20brief\% 20on\%20ageing $\%$ E8\%80\%81\%E9\%BE $\% 84 \% E 5 \% 8 C \% 96 \% E 4 \% B 8 \% A D \% E 6 \% 96 \% 87 . p d f \quad$ (accessed on 23 January 2019).

66. Liu, T.; ten Brink, T. Introduction: International comparative perspectives on Chinese social policy. J. Chin. Gov. 2018, 3, 371-375. [CrossRef] 